study on the mechanical behavior of intervertebral disc using hyperelastic finite element model. Technol Health Care, Preprint, 1-11.

5. Nguyê̂n Thị Thu Hà, Dương Trọng Nghĩa, Nguyển Kim Ngọc (2016). Tác dụng giảm đau và cải thiện chức năng vận động cột sống thắt lưng của điên châm kêt hợp với xônng thuốc $Y$ hoc cổ truyền trên bệnh nhân đau lưng cấp. Tạp chí nghiên cứu y học, 103 (5), 64-70.

6. Nguyễn Đức Minh, Nguyễn Vinh Quốc (2018). Tác dụng điêu trị đau thắt lưng do thoái hóa cột sống bằng thuốc Hoàn chỉ thống kết hợp điện châm. Tap chí Y dược lâm sàng 108, 13 (2) 40-45.

7. Nguyen Vinh Quoc, Nguyen Duc Minh (2019). Research effect of "Hoan chi thong" to treatment rheumatoid arthritis in clinical. Ministry of health Scientific reports the 9th international conference on traditional medicine and folk medicine in Greater MeKong. Ha Noi, Viet Nam. Viet Nam Education Publishing House, 136-143.

8. Minna L Hannuksela, Samer Ellahham (2001). Benefits and risks of sauna bathing. The American Journal of Medicine, 2, 118-126.

\title{
ĐẶC ĐIỂM LÂM SÀNG VÀ KẾT QUẢ ĐIỀU TRI BÊ̂NH NHÂN QUẶM TẠI BÊ̂NH VIỆN MẮT THÁI BìNH
}

\section{Vũ Tuấn Anh'1, Trần Thị Minh Tân², Phạm Trọng Văn ${ }^{3}$}

\section{TÓM TẮT}

Mục tiêu: 1, Mô tả đặc điểm lâm sàng bênh nhân quặm tại Bệnh viện Mắt Thái Bình.2, Đánh giá kết quả điều trị quặm tại Bệnh viện Mắt Thái Bình. Đối tượng và phương pháp nghiền cứu: nghiên cứu can thiệp lâm sàng không đối chứng, bệnh nhân được chẩn đoán quặm và phẫu thuật tai Bệnh viện Mắt Thái Bình tữ tháng 10/2018 đển tháng 8/2019. Kết quả: 33 mắt quặm mi trên tuổi già phẫu thuật bằng phương pháp ghép màng ối đông khô, gấp cân cơ nâng mi; 8 mắt quặm mi dưới tuổi già phẫu thuật bằng phương pháp ghép màng ối đông khô, gấp cần cơ bám mi dưới; 2 mắt quămm do sẹo phẫu thuật bằng phương pháp ghép màng ối đông khô, cắt bỏ sẹo xớ. Triêuu chứng cơ năng giảm rõ rệt sau phẫu thuật: triệu chứng cộm, vướng chí còn $2,3 \%$ sau phẫu thuật 3 tháng. Tỷ lệ thành công $97,7 \%$, tỷ lệ thất bại (tái phát) $2,3 \%, 1$ mắt $(2,3 \%)$ biến chứng trễ mi nhẹ, 1 mắt $(2,3 \%)$ biến chứng u hạt. Kết luận: Để đạt được kết quả tốt nhất sau phẫu thuật về mặt chức năng, thẩm mỹ, hạn chế tối đa tỷ lệ tái phát, phương pháp phẫu thuật phải dựa trên cơ chế gây bệnh. Mặt khác mức độ quặm, tình trạng hàng lông quặm cũng là yếu tố quan trọng tác động đến việc lựa chọn phương pháp phẫu thuật cho phù hợp.

Từ khóa: quặm mi, màng ối đông khô

\section{SUMMARY \\ ASSESSMENT OF CLINICAL CHARACTERISTICS AND TREATMENT RESULTS OF PATIENTS} IN THAI BINH PROVINCE

Objectives: 1, Describe the clinical characteristics of entropion patients in Thai Binh Eye Hospital . 2,

\footnotetext{
${ }^{1}$ Bệnh viện Mắt TW

${ }^{2}$ Trường Đại học Y Dược Thái Bình

${ }^{3}$ Trường Đại hoc Y Hà Nội

Chịu trách nhiệm chính: Vũ Tuấn Anh

Email: vta.oph@gmail.com

Ngày nhận bài: 10.3.2021

Ngày phản biên khoa hoc: 12.5.2021

Ngày duyệt bài: 19.5.2021
}

Evaluate the results of entropion treatment. Materials and methods: non-controlled clinical intervention study Patient was diagnosed with entropion at Thai Binh Eye Hospital from October 2018 to August 2019. Outcomes: 33 eyelids in old age were operated by freeze-dried amniotic membrane grafting method, flexor muscle flexion.8 eyelids under old age were operated by freeze-dried amniotic membrane grafting method, and eyelid muscle flexion was achieved below. 2 entropion due to surgical scars by freeze-dried amniotic membrane grafting, fibrous scar removal. Functional symptoms significantly decreased after surgery. Complications and entanglement are only $2.3 \%$ after 3 months of surgery. Success rate is $97.7 \%$. Failure rate (relapse) $2.3 \%$. There is 1 eye $(2.3 \%)$ complications. mild eyelid delay, 1 eye $(2.3 \%)$ had granulomatous lesion . Conclusion: to achieve the best results after surgery in terms of function, aesthetics, minimize the recurrence rate, the surgical method must be based on the pathogenic mechanism. On the other hand, the degree of entropion and the condition of the ingrown hairs are also an important factor influencing the choice of the appropriate surgical method.

Key words: entropion, freeze-dried amniotic membrane

\section{I. ĐĂT VẤN ĐỀ}

Quặm là hiện tượng bờ mi bị cụp vào trong làm hàng lông mi cọ xát vào giác mạc. Bình thường toàn bộ lông mi mọc theo hướng vểnh ra ngoài, không tiếp xúc với giác mạc. Khi bị quặm có thể toàn bộ hoặc một phân lông mi cọ sát lên giác mạc làm cho bệnh nhân có cảm giác cộm, chói, chảy nước mắt, như có dị vật. Tình trạng quặm kéo dài có thể gây tổn thương lớp biểu mô giác mạc, tạo điều kiện thuận lợi cho bệnh lý giác mạc xảy ra như loét giác mạc, sẹo giác mạc dẫn tới mù lòa ${ }^{1,2}$ Ngoài việc can thiệp vào các tổ chức trên mi mắt, một số tác giả còn sử dụng các loại mảnh ghép nhằm tăng hiệu quả điêuu trị. 
Năm 1974 tác giả Charles và cộng sự sử dụng niêm mạc môi nhờ tính chất dày, dai và ở vị trí dễ lấy, nhưng bệnh nhân phải chịu thêm một vết thương ở môi ${ }^{3,4}$. Năm 2001 tác giả Seng và cộng sự sử dụng màng ối nhờ tính chất dai, liền sẹo nhanh, biểu mô hóa sau 2 tuần, hòa vào màu da sau 2 tuần và chống nhiễm trùng ${ }^{5}$. Tại tỉnh Thái Bình, chúng tôi cũng đã thức hiện phẫu thuât quặm bằng nhiều phương pháp dựa vào cơ chế bệnh sinh. Đặc biệt gần đây, chúng tôi sử dụng màng ối đông khổ để điêu trị quặm, tuy nhiên chưa có nghiên cứu nào thống kể về hiệu quả điêu trị. Vì vậy, chúng tôi tiến hành nghiên cứu này mục tiêu:

1. Mô tả đặc điểm lâm sàng bệnh nhân quặm tại Bênh viên Mắt Thái Bình.

2. Đánh giá kêt quả điều trị quặm tại Bệnh viện Mắt Thái Bình.

\section{II. ĐỐI TƯỢNG VÀ PHƯƠNG PHÁP NGHIÊN CỨU}

2.1. Đối tượng nghiên cứu. Bệnh nhân được chẩn đoán quặm tại Bệnh viện Mắt Thái Bình từ tháng 10/2018 đến tháng 8/2019. Những bệnh nhân được lựa chọn phải đủ tiêu chuẩn chẩn đoán bị quặm là có biến dạng hình thể của mi mắt và bờ tự do của mi cụp vào làm cho lông mi co xát với giác mạc ở bất kỳ vị trí nào.

Tiêu chuẩn lựa chọn bệnh nhân

- Bệnh nhân quặm do sẹo: di chứng bỏng, chấn thương, mắt hột, hội chứng Steven-Johnson.

- Bệnh nhân bị quặm tái phát.

- Bệnh nhân quặm tuổi già.

- Bệnh nhân quặm bẩm sinh.

\section{Tiêu chuẩn loại trừ bệnh nhân}

- Bệnh nhân không hợp tác với thầy thuốc trong quá trình khám và điều trị.

- Bệnh nhân đang mắc các bệnh mắt khác như viêm màng bồ đào, loét giác mạc nặng, glôcôm.

- Bệnh nhân mắc bệnh toàn thân nặng như cao huyết áp, suy tim, suy hô hấp chưa được điều trị ổn đinh.

\subsection{Thiết kế và qui trình nghiên cứu}

Nghiên cứu can thiệp lâm sàng không đối chứng.

Thu thập các thông tin cơ bản: tuổi, giới, thời gian mắc bệnh

\section{Khám mắt}

Khám chức năng: bệnh nhân được đo thị lực không kính, thị lực có chỉnh kính

Thị lực được chia thành các mức độ

+ Thị lực <20/200

+ Thị lực từ 20/200 - <20/30

+ Thị lực từ 20/30

*Khám triệu chứng- Tình trạng lông mi: lông mi cọ sát vào giác mạc nhiêu hay ít. Vị trí của hàng lông mi cọ sát vào giác mạc.

\section{Thực thể:}

- Tình trạng mi mắt

+ Khám phát hiện sẹo trên mi sau chấn thương, sau bệnh mắt hột, sau bỏng.

Sau chấn thương mi mắt có thể có sẹo co kéo, xoắn vặn làm thay đổi bờ mi và hướng đi của lông mi. Lộn mi lên có thể thấy sẹo kết mạc co kéo trong bệnh mắt hột, thấy di chứng của bệnh mắt hột.

+ Khám tình trạng da mi để phát hiện dấu hiệu sa da mi, sụp mi, mất nếp mi, bờ mi cuộn vào trong.

+ Khám tình trạng cơ để phát hiện giảm trương lực cơ, nhão cơ.

+ Khám tình trạng sụn để phát hiện teo sụn, mỏng sụn.

-Tình trạng kết mạc: viêm, di chứng hột, sẹo, sừng hóa.

- Tình trạng giác mạc: loét giác mạc, sẹo giác mạc, Iõm hột.

*Thực hiện một số nghiệm pháp để đánh giá trương lực dầy chằng.

- Nghiệm pháp kéo mi xuống dưới: dùng hai ngón trỏ kéo phần chính giữa mi xa khỏi nhãn cầu. Sau đó buông tay ra, nếu tình trạng nhão $\mathrm{mi}$ (nhão dây chằng $\mathrm{mi}$ trong và dây chằng $\mathrm{mi}$ ngoài) mi vẫn rời khỏi nhãn cầu, chúng chỉ trở về vị trí ban đầu khi nháy mắt 2 lấn.

- Nghiệm pháp đánh giá dây chằng mi trong: kéo mi ra phía ngoài và quan sát điểm lệ di lệch. Nếu điểm lệ di lệch $>2 \mathrm{~mm}$ là giảm trương lực dây chằng mi trong.

- Nghiệm pháp đánh giá dây chằng mi ngoài: kéo mi vào phía trong và quan sát điểm lệ di lệch. Nếu điểm lệ di lệch >2mm là giảm trương lực dây chằng mi ngoài.

*Thực hiện nghiệm pháp đánh giá trương lực mi dưới.

- Nghiệm pháp kéo mi ra trước: nắm nhe lên da mi dưới và kéo bờ mi ra xa nhãn cầu. Nếu mi dưới tách rời khỏi nhãn cầu $>10 \mathrm{~mm}$ là giảm trương lực mi dưới. Hoặc kéo bờ mi xuống dưới yêu câu bệnh nhân khổng chớp mắt. Bỏ tay và quan sát bờ mi trở lại vị trí cũ. Mi trở lại vị trí cũ chậm hoặc phải chớp mắt thì trương lực mi dưới giảm.

- Quan sát vận động của mi dưới khi mắt liếc xuống dưới. Vận động này có thể giảm nếu cơ bám mi dưới giảm trương lực. Nếu cơ bám mi dưới không còn bám vào sụn mi, mi sẽ xoay vào trong hay ra ngoài. Nếu cớ bám mi dưới rất giãn hoặc bị rời ra khỏi chỗ bám cùng đồ sẽ sâu hơn bình thường.

*Đánh giá chức năng cơ nâng mi. 
- Để đánh giá chức năng cơ nâng mi cần đo biên độ vận động của cơ nâng mi. Dùng tay cô định cung mày, yêu cầu bệnh nhân nhìn lên tối đa sau đó nhìn xuống tối đa và đo khoảng vận động của bờ mi trên. Nếu khoảng này $>13 \mathrm{~mm}$ là chức năng cơ nâng mi tốt.

- Đo khoảng cách từ nếp mi đến lông mi. Khoảng cách này thay đổi nếu giãn cân cơ nâng mi.

Đạo đức nghiên cứu. Nghiên cứu tuân thủ các qui tắc đạo đức trong nghiên cứu $Y$ sinh học, được thông qua Hội đồng đạo đức và được mã hóa, giữ bí mật thông tin của bệnh nhân.

\section{KẾT QUẢ VÀ BÀN LUÂ̂N}

Nghiên cứu của chúng tôi thực hiện trên 25 bệnh nhân với 43 mi mắt bị quặm được khám và điều trị tại Bệnh viện Mắt Thái Bình.

\section{1. Đăc điểm của bênh nhân.}

\subsubsection{Tuối, giới và typ ĐTÐ}

Phân bố bệnh nhân theo giới.

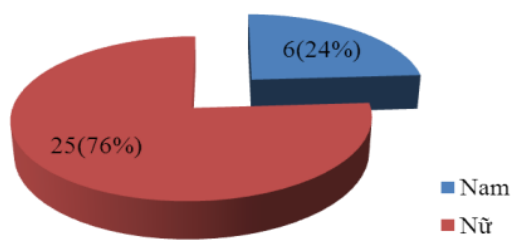

Biểu đồ 3.1. Phân bố bênh nhân theo giới.

Nhóm nghiên cứu của chúng tôi có 25 bệnh nhân trong đó có:- 6 bệnh nhân nam chiếm 24\%

- 19 bệnh nhân nữ chiếm 76\%

Như vậy bệnh nhân nữ mắc bệnh nhiều hơn bệnh nhân nam. Sự khác biệt có ý nghĩa thống kể với $p<0,05$. Kết quả cho thấy bệnh nhân quăm do tuổi già gặp ở nữ giới nhiều hơn nam giới. Các tác giả nghiên cứu quặm tuổi già cũng cho kết quả bệnh gặp ở nữ giới nhiều hơn nam giới. Các tác giả cho rằng bản sụn ở nữ thấp hơn ở nam, tình trạng mỏng sụn, teo sụn xảy ra sớm hơn. Đây là lý do làm cho quặm gặp ở nữ nhiều hơn nam ${ }^{1,3}$.

\subsubsection{Phân bố bệnh nhân theo tuổi}

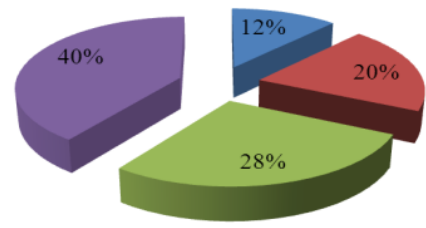

घ $<60$

- $60-69$

$\square$ - 70-79

$=80$

Biểu đồ 3.2. Phân bố bệnh nhân theo nhóm tuổi
Tuổi trung bình của nhóm nghiên cứu là $74,04 \pm 8,17$. Trong đó người nhiều tuổi nhất là 89 tuổi, người ít tuổi nhất là 52 tuổi. Người 52 tuổi bi quăm do seo.

- Nhóm tuổi trên 80 có 10 bênh nhân chiếm 40\%

- Nhóm tuổi từ 70 đến 79 có 7 bệnh nhân chiếm $28 \%$

- Nhóm tuổi từ 60 đến 69 có 5 bênh nhân chiếm $20 \%$

- Nhóm tuổi dưới 60 có 3 bệnh nhân chiếm $12 \%$. Trong nhóm này có 2 bệnh nhân quămm do sẹo.

3.2. Đặc điểm mi mắt liên quan đến quặm Tình trang mi măt.

Bảng 3.1. Phân bố đặc điểm mi mắt, lông mi của quặm mi trên.

\begin{tabular}{|c|c|c|}
\hline Đặc điếm mi măt & n (măt) & Tỷ lệ (\%) \\
\hline Sa da mi & 16 & 47,1 \\
\hline Sụp mi & 3 & 8,8 \\
\hline Teo sụn & 9 & 26,5 \\
\hline Mỏng sụn & 17 & 50,0 \\
\hline $\begin{array}{c}\text { Giảm trương lực cân cơ } \\
\text { nâng mi }\end{array}$ & 21 & 61,8 \\
\hline Sẹo co kéo mi & 1 & 2,9 \\
\hline Hàng lông mi kép & 9 & 26,5 \\
\hline $\begin{array}{c}\text { Lông quặm mọc nhiều } \\
\text { hướng, nhiều hàng }\end{array}$ & 24 & 70,6 \\
\hline
\end{tabular}

Nhóm bệnh nhân được nghiên cứu có 34 mắt bị quăm mi trên. Các biến đổi của mi mắt trên do tuổi già là chủ yếu. Chỉ có 1 mắt $(1 \mathrm{mi})$ tổn thương trên mi mắt là dải sẹo xơ co kéo.

- Sa da mi có 16 mắt, chiếm tỷ lệ 47,1\%

- Sụp mi có 3 mắt, chiếm tỷ lệ $8,8 \%$

- Teo sụn có 9 mắt, chiếm tỷ lệ $26,5 \%$

- Mỏng sụn có 17 mắt, chiếm tỷ lệ 50,0\%

- Giảm trương lực cân cơ nâng mi có 21 mắt, chiếm tỷ lệ $61,8 \%$

- Hàng lông mi kép có 9 mắt, chiếm tỷ lệ $26,5 \%$. Cả 9 mắt này xuất hiện một hàng lông mi sát lố tuyến Meibomius ở $1 / 2$ ngoài bờ mi và co sát vào giác mạc trong mọi hướng nhìn.

- Hàng lông mi mọc nhiều hướng, nhiều hàng có 24 mắt, chiếm tỷ lệ 70,6\%.

Bảng 3.2. Phân bố đặc điểm mi mắt, lông mi của quăm mi dưới

\begin{tabular}{|c|c|c|}
\hline Đặc điểm mi dưới & $\begin{array}{c}\mathbf{n} \\
\text { (mắt) }\end{array}$ & $\begin{array}{c}\text { Tỷ lệ } \\
\text { (\%) }\end{array}$ \\
\hline $\begin{array}{c}\text { Mất chô̂ bám cân cơ bám } \\
\text { mi dưới }\end{array}$ & 8 & 88,9 \\
\hline Mỏng sụn & 4 & 44,4 \\
\hline Sẹo co kéo mi dưới & 1 & 11,1 \\
\hline Hàng lông mi kép & 1 & 11,1 \\
\hline $\begin{array}{c}\text { Lông quặm mọc nhiều } \\
\text { hướng, nhiều hàng }\end{array}$ & 7 & 77,8 \\
\hline
\end{tabular}


Nhóm bệnh nhân được nghiên cứu có 9 mắt bị quặm mi dưới. Trong đó gặp các biến đổi mi mắt như sau:

- Mất chỗ bám cân cơ bám mi dưới có 8 mắt, chiếm tỷ lệ 88,9\%

- Mỏng sụn có 4 mắt, chiếm tỷ lệ 44,4\%

- Seo co kéo mi dưới có 1 mắt, chiểm tỳ lệ 11,1\%

- Hàng lông mi kép có 1 mắt, chiếm tỳ lệ 11,1\%

- Lông quă̆m mọc nhiều hướng, nhiều hàng có 7 mắt, chiểm tỷ lệ $77,8 \%$

Như vậy cả mi trên và mi dưới sự biến đổi chủ yếu do tuổi già.

\subsection{Kết quả điêu trị}

Bảng 3.3. Phương pháp phẫu thuật

\begin{tabular}{|c|c|c|}
\hline Phương pháp phẫu thuật & $\begin{array}{c}\text { n } \\
\text { (mắt) }\end{array}$ & $\begin{array}{c}\text { Tỷ lệ } \\
(\mathbf{\%})\end{array}$ \\
\hline $\begin{array}{c}\text { Ghép màng ối đông khô, gấp } \\
\text { cân cơ nâng mi }\end{array}$ & 33 & 76,7 \\
\hline $\begin{array}{c}\text { Ghép màng ối đông khô, gấp } \\
\text { cơ bám mi dưới }\end{array}$ & 8 & 18,6 \\
\hline $\begin{array}{c}\text { Ghép màng ối đông khô, cắt } \\
\text { bỏ sẹo }\end{array}$ & 2 & 4,7 \\
\hline Tống & $\mathbf{4 3}$ & $\mathbf{1 0 0}$ \\
\hline
\end{tabular}

Chúng tôi đã thực hiện 3 phương pháp phấu thuật tùy thuộc vào nguyên nhân gây ra quặm, mức độ quặm. Trên thế giới và tại Việt Nam đã có nhiểu nghiên cứu về các phưởng pháp phẫu thuật quặm. Mỗi phương pháp đều có những ưu điểm và nhược điểm. Các tác giả đã chỉ ra rằng: để có sự thành công sau phẫu thuật quặm phải dựa vào cơ chế gây ra bệnh.

3.3.1. Tình trạng mảnh ghép (màng ối đông khô) sau phầu thuật. Đánh giá tình trạng mảnh ghép là một trong những yếu tố quan trọng, quyết định đến sự thành công hay thất bại của phương pháp phẫu thuật ${ }^{4,5}$. Màng ối như một màng sinh học phủ lên vết thương ở bờ mi được tạo ra sau phẫu thuật. Màng ối bám tốt, mới tạo điều kiện cho mép mổ liền tốt, tổ chức da tái tạo nhanh đóng kín mép mổ và ngăn cản sự nhiếm trùng vết mổ, tái tạo lại một bờ mi hoàn chỉnh cho bênh nhân.

Sau phẫu thuật 1 tuần tất cả mảnh ghép tốt. Mảnh ghép trong, bóng, phẳng, bám vào nền nhận (diện bờ mi được phẫu tích).

Sau phẫu thuật 1 tháng xuất hiện 1 mắt có mảnh ghép xấu. Chúng tôi nhận thấy, mảnh ghép không phẳng, có su hướng co lại, mép của mảnh ghép từng chỗ bật khỏi mép mổ làm cho tổ chức da khó bắt vào. Giữa mép da và mép mảng ghép có những đoạn bị tách khỏi nhau. Đây là mắt quặm mi trên, mức độ nặng, lông quặm mọc thành nhiêu hàng. Chúng tổi đã rạch bờ mi, phẫu tích rộng về phía da, cắt bỏ một phần lông quă̆m (hàng lông quặm trong cùng) nên diện vết thương ở bờ mi rộng. Có thể trường hợp này, chúng tôi đã để mảnh ghép hơi nhỏ hơn so với nền nhận. Tuy mảnh ghép xấu nhưng tình lông mi không cọ xát vào giác mạc. Nên tại thời điểm đó, chúng tôi xử trí bằng cách khâu tăng cường mép mảnh ghép với mép da tại những vị trí bị bong và tiếp tục theo dõi bệnh nhân.

Sau phẫu thuật 3 tháng có 42 mắt mảnh ghép tốt. Toàn bộ mảnh ghép ở 42 mắt đều phẳng, tổ chức da bắt vào mảnh ghép tốt, tái tạo bờ mi hồng. Tuy nhiên có 1 mắt mảnh ghép rất xấu. Đó là mắt, tại thời điểm 1 tháng mảnh ghép có biểu hiện bong. Đến thời điểm 3 tháng, mảnh ghép này tiếp tục co nhỏ, dính đét vào bờ mi thành đám, làm vết mổ xấu, bờ mi gồ ghề, xuất hiện một chùm lông mi phía ngoài cọ xát vào giác mạc. Tại thời điểm này, chúng tôi quyết định xử trí thay mảnh ghép màng ối bằng niêm mac môi và tiếp tục theo dõi bênh nhân. Có thể mảnh ghép niêm mạc môi sẽ rộng, dày hơn màng ối, nên khả năng bám dính vào nền nhận tốt ${ }^{4}$. Vì vậy với những mắt, phần rạch bờ mi rộng cần phải lấy màng ối rộng và gấp thành nhiều lớp tạo độ dày 5 .

3.3.2. Mức độ vểnh của lông mi. Độ vểnh của lông mi là một trong những yếu tổ quan trọng để đánh giá sự thành công sau phẫu thuật. Độ vểnh của mi không tốt sẽ có nguy cơ tái phát, độ vểnh của mi nhiều quá ảnh hưởng đến mặt thẩm mỹ của bệnh nhân.

Độ vểnh lông mi sau phẫu thuật được đánh giá là tốt khi mi vểnh 50 đến 60 độ. Tại thời điểm sau phẫu thuật 1 tuần $100 \%$ lông mi vểnh tốt. Đến thời điểm 1 tháng sau phẫu thuật xuất hiện 3 mắt $(7 \%)$ có độ vểnh lông mi ở mức độ trung bình. Cả 3 mắt này lông mi có su hướng cụp vào trong, độ vểnh của lông mi dưới 50 độ, tuy nhiên chưa cọ xát vào giác mạc. Những mắt có độ vểnh lông mi trung bình đểu bị quặm mi trên, mức độ nặng. Sau 3 tháng phẫu thuật, chúng tôi nhận thấy, trong 3 mắt có độ vểnh lông mi ở mức trung bình xuất hiện 1 mắt $(2,3 \%)$ lông mi cọ vào giác mạc. Mắt này chính là mắt có mảnh ghép xấu, quặm tái phát lại. Trong 43 mắt được nghiên cứu, sau 3 tháng phẫu thuật có 40 mắt $(93,0 \%)$ độ vểnh lông mi tốt, 2 mắt $(4,7 \%)$ độ vểnh lông mi trung bình, 1 mắt $(2,3 \%)$ độ vểnh lông mi xấu. Những mắt độ vểnh lông mi trung bình có nguy cơ quặm tái phát.

3.3.3. Biến chứng sau phẫu thuật.Theo các tác giả, biến chứng sau phẫu thuật quặm có thể gặp là: hở mi, trễ mi, khấc mi, u hạt. Đối với những phẫu thuật ghép tổ chức có thể gặp biến 
chứng xuất huyết dưới mảnh ghép, phì đại mảnh ghép ${ }^{5}$.

Nghiên cứu của chúng tôi gặp 2 biến chứng, 1 mắt $(2,3 \%)$ bị trễ mi, 1 mắt $(2,3 \%)$ bị u hạt. Cả hai biến chứng này xuất hiên tại thời điểm 1 tháng sau phẫu thuật. Tuy nhiên tại thời điểm này, chúng tôi nhận thấy tình trạng trễ mi nhẹ, không ảnh hưởng nhiêu đến chức năng và thẩm mỹ nên không xử trí gì, tiếp tục theo dõi. Mắt bị trể mi sau phầu thuật ghép màng ối, gấp cân cơ bám mi dưới. Một mắt bị u hạt ở góc ngoài còn rất nhỏ, nên chúng tôi không xử trí, tiếp tục theo dõi. Mắt bị u hạt ở mi trên, có thể do mép khâu giữa màng ối và da mi không kín, tạo một khe hở, mảnh ghép không được kéo căng, hình thành $u$ hạt. Đến thời điểm 3 tháng sau phẫu thuật, u hạt phát triển lớn hơn, chúng tôi đã xử trí bằng cách bóc tách cắt bỏ cho bênh nhân.

\subsubsection{Thị lực sau điêu trị.}

Bảng 3.3. Thay đổi thị lực tại các thời điểm theo dối sau phẫu thuật

\begin{tabular}{|c|c|c|c|c|c|c|}
\hline \multirow{2}{*}{ Thay đổi thị lực } & \multicolumn{2}{|c|}{ 1 tuân } & \multicolumn{2}{c|}{ 1 tháng } & \multicolumn{2}{c|}{ 3 tháng } \\
\cline { 2 - 7 } & $\mathbf{n}$ & $\mathbf{\%}$ & $\mathbf{n}$ & $\mathbf{\%}$ & $\mathbf{n}$ & $\mathbf{\%}$ \\
\hline Thị lực tăng & 0 & 0 & 1 & 2,3 & 1 & 2,3 \\
\hline Thị lực giảm & 0 & 0 & 0 & 0 & 5 & 11,6 \\
\hline Thị lực không đối & 43 & 100 & 42 & 97,7 & 37 & 86,1 \\
\hline
\end{tabular}

Như vậy tại các thời điểm theo dõi 1 tháng, 3 tháng, thị lực của bệnh nhân thay đổi như sau:

- Tại thời điểm 1 tháng: 1 mắt $(2,3 \%)$ thị lực tăng, không có mắt nào thị lực giảm, 42 mắt $(97,7)$ thị lực không thay đổi.

- Tai thời điểm 3 tháng: 1 mắt $(2,3 \%)$ thi lực tăng, 5 mắt $(11,6 \%)$ thị lực giảm, 37 mắt
$(86,1 \%)$ thị lực không thay đổi.

Khi so sánh $\mathrm{p}$ trước phẫu thuật và sau phẫu thuật tại các thời điểm theo dõi $p>0,05$. Sự thay đổi thị lực sau phẫu thuật không có ý nghĩa thống kê. Như vậy thị lực của bệnh nhân không thay đổi tai các thời điểm theo dõi sau phẫu thuật so với trước phẫu thuật

\subsubsection{Triệu chứng cơ năng của bệnh nhân sau phẫu thuât.}

Bảng 3.4. Triệu chứng cơ năng tại các thời điểm sau phẩu thuật

\begin{tabular}{|c|c|c|c|c|c|c|c|c|c|}
\hline \multirow{2}{*}{$\begin{array}{l}\text { Triệu } \\
\text { chứng }\end{array}$} & \multicolumn{2}{|c|}{$\begin{array}{l}\text { Trước } \\
\text { phẫu thuâat (1) }\end{array}$} & \multicolumn{2}{|c|}{1 tuần (2) } & \multicolumn{2}{|c|}{1 tháng (3) } & \multicolumn{2}{|c|}{3 tháng (4) } & \multirow{2}{*}{$\mathbf{p}$} \\
\hline & $n$ & $\%$ & $\mathrm{n}$ & $\%$ & $\mathrm{n}$ & $\%$ & $\mathbf{n}$ & $\%$ & \\
\hline $\begin{array}{l}\text { Cộm, } \\
\text { vướng }\end{array}$ & 40 & 93 & 9 & 20,9 & 4 & 9,3 & 1 & 2,3 & $\begin{array}{l}\mathrm{p}_{1,2}<0,05 \\
\mathrm{p}_{1,3}<0,05 \\
\mathrm{p}_{1,4<0,05}\end{array}$ \\
\hline $\begin{array}{l}\text { Chảy nước } \\
\text { mắt }\end{array}$ & 35 & 81,4 & 7 & 16,3 & 1 & 2,3 & 1 & 2,3 & $\begin{array}{l}\mathrm{p}_{1,2}<0,05 \\
\mathrm{p}_{1,3}<0,05 \\
\mathrm{p}_{1,4}<0,05\end{array}$ \\
\hline $\begin{array}{c}\text { Chói mắt, } \\
\text { sớ ánh } \\
\text { sáng }\end{array}$ & 12 & 27,9 & 6 & 14,0 & 1 & 2,3 & 1 & 2,3 & $\begin{array}{l}\mathrm{p}_{1,2}>0,05 \\
\mathrm{p}_{1,3}<0,05 \\
\mathrm{p}_{1,4}<0,05\end{array}$ \\
\hline
\end{tabular}

Biểu hiên của các triêu chứng cơ năng sau phẫu thuật tại các thời điểm theo dõi như sau:

- Triệu chứng cộm, vướng: sau 1 tuần còn 9 mắt $(20,9 \%)$. Sau 1 tháng còn 4 mắt $(9,3 \%)$. Sau 3 tháng còn 1 mắt $(2,3 \%)$. So sánh với thời điểm trước phẫu thuật, triệu chứng cộm, vướng giảm rõ rệt. Sự khác biệt này có ý nghĩa thống kê với $p<0,05$.

- Triêu chứng chảy nước mắt: sau 1 tuần còn 7 mắt $(16,3 \%)$. Sau 1 tháng còn 1 mắt $(2,3 \%)$. Sau 3 tháng còn 1 mắt $(2,3 \%)$. So sánh với thời điểm trước phẫu thuật, triệu chứng chảy nước mắt giảm rõ rệt. Sự khác biệt này có ý nghĩa thống kê với $p<0,05$.

- Triệu chứng chói mắt, sợ ánh sáng: sau 1 tuần còn 6 mắt $(14,0 \%)$. Sau 1 tháng còn 1 mắt
$(2,3 \%)$. Sau 3 tháng còn 1 mắt $(2,3 \%)$. So sánh với thời điểm trước phẫu thuật, triệu chứng chói, sợ ánh sáng tại thời điểm 1 tuần không có sự khác biệt với $p>0,05$, tại thời điểm 1 tháng, 3 tháng, sự khác biệt có ý nghĩa thống kê với $\mathrm{p}<$ 0,05 . Như vậy sau điều trị từ 1 tháng trở lên triệu chứng chói, sợ ánh sáng mới giảm. Sự cải thiên về mặt chức năng này là do sau khi hết quặm một thời gian, giác mạc mới được biểu mô hóa hoàn toàn.

\section{KẾT LUÂNN}

Nghiên cứu trên 25 bênh nhân, 43 mắt. Tuổi trung bình của nhóm bệnh nhân nghiên cứu là $74,04 \pm 8,17$, trong đó nhóm tuổi từ 80 trở lên chiếm tỳ lệ $40 \%$. Nữ bị quặm nhiều hơn nam 
(76\%/24\%). Triệu chứng cơ năng trước phẫu thuật hay gặp nhất là cộm, vướng, chiếm tỷ lệ 93\%. Có 33 mắt quặm mi trên tuổi già phẫu thuật bằng phương pháp ghép màng ối đông khô, gấp cân cơ nâng mi.8 mắt quặm mi dưới tuổi già phẫu thuật bằng phương pháp ghép màng ối đông khô, gấp cân cơ bám mi dưới.2 mắt quặm do sẹo phẩu thuật bằng phương pháp ghép màng ối đông khô, cắt bỏ sẹo xơ. Thị lực không cải thiện sau phẫu thuật. Triệu chứng cơ năng giảm rõ rệt sau phẫu thuật. Triệu chứng cộm, vướng chỉ còn 2,3\% sau phẫu thuật 3 tháng. Chất lượng phẫu thuật quặm ở Việt Nam hiện nay cân được cải thiện, kỹ thuật phải căn cứ vào cơ chế gây quặm.

\section{TÀI LIẸU THAM KHẢO}

1. Phan Dẫn, Phạm Trọng Văn (1998), Phẫu thuật tao hình mi mắt. Nhà xuất bản $Y$ hoc

2. Hà Huy Tài và CS (1996), Điều tra dịch tễ hoc mù lòa và một số bệnh về mắt. Công trinh nghiển cứu cấp bộ.Viên Mắt.

3.Damasceno R.W., Osaki M.H., Dantas P.E.C., et al. (2011). Involutional entropion and ectropion of the lower eyelid: prevalence and associated risk factors in the elderly population. Ophthal Plast Reconstr Surg, 27(5), 317-320.

4. Alston Callahan (1976). Correction of Entropion From Stevens-Johnson Syndrome. Arch Ophthalmol, Vol 94,pp. 1154-1155.

5. Charles R. Leone (1974). Mucous Membrane Graft for Cicatricial Entropion. Ophthalmic surgery, Vol 5, No 2, pp.24-28.

\section{KIẾN THỨC, THÁI Độ, THỰC HÀNH PHÒNG NGỪA ĐIẾC NGHỀ NGHIỂP CỦA NGƯỜI LAO ĐÔNG} TẠI NHÀ MÁY TINH BỘT SẮN ĐỒNG XUÂN, PHÚ YÊN, 2018

\section{TÓM TẮT}

Điếc nghề nghiệp do tiếng ồn nơi làm việc là một trong những bệnh nghề nghiệp được bảo hiểm phổ biến nhất ở Việt Nam. Sản xuất và chế biến thực phẩm là một trong những ngành nghề có môi trường làm việc ô nhiễm với tiếng ồn, chỉ sau môtt số ngành công nghiệp, khai thác. Nghiên cứu đã được tiến hành với mục đích tìm hiểu mức kiến thức, thái đô và thực hành của người lao động tại đây trong việc phòng ngừa điếc nghề nghiêp và môt số yếu tố liên quan. Nghiên cứu mô tả cắt ngang đã được tiến hành khảo sát trên 125 công nhân tham gia lao động trực tiếp tại nhà máy. Kết quả nghiên cứu cho thấy tỷ lệ người lao động có kiến thức đúng về phòng ngừa điếc nghề nghiệp chưa cao, chiếm tỷ lệ 69,6\%; Nội dung về kiến thức mà phần lớn người lao động khống biết là giới hạn tiếng ồn tối đa cho phép trong 8 giờ theo quy định hiện nay, chỉ có $37,6 \%$ người lao động có kiến thức đúng về vấn đề này; Tỷ lệ người lao động có thái độ tốt là tương đối cao $(72 \%)$. Tuy nhiên, chỉ có $52,8 \%$ người lao động có thực hành đúng trong việc phòng ngừa điếc nghề nghiệp.

Tư khoá: tiếng ồn, nhà máy chế biến thực phẩm, kiến thức, thái độ, thực hành, điếc nghề nghiệp

\section{SUMMARY \\ KNOWLEDGE, ATTITUDE AND PRACTICE}

\footnotetext{
${ }^{1}$ Trường Đại học Y tế công cộng

${ }^{2}$ Trung tâm kiểm soát bênh tât tỉnh Phú Yên

Chịu trách nhiệm chính: Nguyễn Ngọc Bích

Email: nnb@huph.edu.vn

Ngày nhận bài: 15.3 .2021

Ngày phản biên khoa hoc: 10.5.2021

Ngày duyệt bài: 19.5.2021
}

Nguyễn Ngọc Bích ${ }^{1}$, Phan Thị Lan Phương

ON OCCUPATIONAL HEARRING LOSS

PREVENTION AMONG WORKERS AT DONG XUAN TAPIOCA STARCH PROCESSING COMPANY, 2018 AND SOME RELATED FACTORS

Occupational hearing loss is one of the most common occupational diseases in Vietnam. Food processing is one of the sectors that have high working environment pollution, just only lower than some industries like mining. Thís study aimed to investigate knowledge, attitude and practice of workers on hearring loss prevention and some related factors. A cross sectional study was conducted in 125 workers. Results show that the prevalence of workers who had adequate knowledge on hearring loss prevention was not so high (only 69.6\%). Almost all of them did not know the noise limit at work while working for 8 hours. There were $72 \%$ of workers who had adequate attitude. But only $52.8 \%$ of workers practiced adequately on occupational hearring loss prevention.

Keywords: food processing, knowledge, attitude, practice, occupational hearring loss

\section{I. ĐẶT VẤN ĐỀ}

Theo kết quả nghiên cứu mới nhất về những gánh nặng bệnh tật toàn cầu cho thây tình trạng giảm thính lực đang tăng lên và hiện đang ở mức báo động. Tại Hoa kỳ, điếc nghề nghiệp là bệnh lý mãn tính liên quan đến nghề nghiệp đứng thứ 3 sau các bệnh ung thư và tiểu đường. Theo tổng cục thống kê lao động Hoa Kỳ thì hầu hết các ngành công nghiệp thực phẩm và đồ uống có các quy trình phát ra tiếng ồn cao hơn mức $85 \mathrm{~dB}$. Ví dụ mức độ tiếng ồn phát ra trong 